\title{
ON THE NATURAL DIET OF Daphnia laevis IN THE EUTROPHIC PAMPULHA RESERVOIR (BELO HORIZONTE, MINAS GERAIS)
}

\author{
ESKINAZI-SANT’ANNA, E. M., MAIA-BARBOSA, P. M. and BARBOSA, F. A. R. \\ Universidade Federal de Minas Gerais, Laboratório de Limnologia/Ecologia do Zooplâncton, ICB/B1, I3/253, \\ Av. Antônio Carlos, 2267, CEP 31270-901, Pampulha, Belo Horizonte, Brazil \\ Correspondence to: Eneida M. Eskinazi-Sant'Anna, Universidade Federal de Minas Gerais, Laboratório de \\ Limnologia/Ecologia do Zooplâncton, ICB/B1, I3/253, Av. Antônio Carlos, 2267, CEP 31270-901, \\ Pampulha, Belo Horizonte, Brazil, e-mail: eskinazi@mono.icb.ufmg.br \\ Received May 17, 2001 - Accepted August 17, 2001 - Distributed August 31, 2002
}

(With 5 figures)

\begin{abstract}
The aim of this study was to assess the major food items ingested by adult specimens of Daphnia laevis within the eutrophic Pampulha reservoir in Belo Horizonte, Minas Gerais, Brazil. The gut content was analyzed after addition of sodium hypochlorite and also through the examination of dissected guts under scanning electron microscopy. The results showed that Chlorophyceae was the main food item ingested, representing $c$. $80.5 \%$ of the total ingested food. Moreover, Eutetramorus fottii, Coelastrum pseudomicroporum and Oocystis lacustris, the dominant phytoplankton species within the reservoir, were the most frequent cells found in the gut contents. Euglenophyta also represented an important food item accounting for $15 \%$ of the ingested material, including mainly Trachelomonas volvocina and Euglena oxyuris, although less abundant in the reservoir ( $<10 \%$ of total phytoplankton). Blue-green algae occurred at much lower percentages in the guts than in the phytoplankton. A small amount of undigested Microcystis aeruginosa colonies were also found in the gut content of $D$. laevis. Scanning electron microscopy results showed that, besides phytoplankton cells, a great amount of abiogenic material was also ingested. The amount of this inorganic material increased considerably in the tract (from $15 \%$ to $75 \%$ of the gut content), when a peak of $D$. laevis was observed in the reservoir. Our assumption is that the ingestion of this inorganic material can be a strategy used by D. laevis to obtain additional food supply.
\end{abstract}

Key words: Daphnia laevis, natural diet, reservoir, eutrophication.

\section{RESUMO}

Dieta natural de Daphnia laevis no reservatório eutrófico da Pampulha (Belo Horizonte, Minas Gerais)

Com o objetivo de verificar a composição dos itens alimentares utilizados por Daphnia laevis no reservatório eutrofizado da Pampulha (Belo Horizonte, MG), foi analisado o conteúdo do trato digestivo de indivíduos adultos, por intermédio das técnicas de clarificação e microscopia eletrônica de varredura. Os resultados obtidos mostraram que Chlorophyceae foi o principal item alimentar ingerido por Daphnia laevis $(80,5 \%)$. As espécies mais freqüentes no trato digestivo foram: Eutetramorus fottii, Coelastrum pseudomicroporum e Oocystis lacustris, que corresponderam às mais abundantes no reservatório. Euglenophyta também representou importante item alimentar (15\%), especialmente Trachelomonas volvocina e Euglena oxyuris, embora tenham apresentado abundância reduzida no ambiente ( $<10 \%$ do fitoplâncton total). Cyanophyceae esteve praticamente ausente no trato digestivo, tendo sido encontrada apenas pequena quantidade de colônias não digeridas de Microcystis aeruginosa. Os resultados obtidos na microscopia eletrônica de varredura mostraram, além do fitoplâncton, a presença de material abiogênico. A participação desse material inorgânico no tubo digestivo aumentou consideravelmente (de $15 \%$ para $75 \%$ de preenchimento do trato digestivo) quando um pico de $D$. 
laevis foi observado no reservatório. Os resultados obtidos sugerem que a ingestão de material abiogênico parece ser uma estratégia na captação de recursos alimentares adicionais.

Palavras-chave: Daphnia laevis, dieta natural, reservatório, eutrofização.

\section{INTRODUCTION}

In aquatic ecosystems, the structure and dynamics of zooplanktonic populations are strongly influenced by food availability, which is the result of the prevailing trophic conditions of the system. Several studies have correlated changes in species composition, size-structure and biomass in aquatic ecosystems with eutrophication (Bays \& Crisman, 1983; Infante \& Riehl, 1984; Mayer et al., 1997). Since the herbivorous zooplankton plays a key role within aquatic food chains, the interactions between zooplankton and phytoplankton in eutrophic systems are of paramount importance to the understanding of the structure and functioning of these ecosystems (Nõges, 1997).

Despite the fact that the feeding behaviour of the zooplankton is directly involved with the nutrient cycling, energy transference, and productivity of the aquatic ecosystems, in situ studies showing direct observations on the ingested material are still scarce, especially in tropical systems. Furthermore, the majority of the studies concerning Cladocera feeding habits have been conducted under laboratory conditions, using unialgal cultures or limited food sources (Hanazato \& Yasuno, 1987; Demott, 1988; Hartmann \& Kunkel, 1991; Repka, 1997).

The objective of the present study was to assess the natural diet of Daphnia laevis within a eutrophic reservoir, through analysis of the gut content under both optical and scanning electron microscopy.

\section{STUDY AREA}

Pampulha reservoir is a shallow urban water body, located in the southeast of Brazil (1955'09'S; 4356'47' W). The reservoir has an accumulated volume of 12 million $\mathrm{m}^{3}$, an area of $2.4 \mathrm{~km}^{2}$, and an average depth of $6 \mathrm{~m}$ (Fig. 1). The reservoir was built in 1938, re-built in 1952 and since then has been under a continuous eutrophication process mainly due to domestic and industrial discharges, mostly untreated. Three of its major tributaries (Ressaca, Sarandi and Água Funda) are responsible for c. $98 \%$ of all the nitrogen entering the reservoir $(6,000$ and $3,000 \mu \mathrm{g} / \mathrm{L}$, respectively) rendering charges of $406 \mathrm{~kg} / \mathrm{day}$ (dry season) and $454 \mathrm{~kg} / \mathrm{day}$ (raining season). For phosphorous, these streams are also the major contributors with concentrations higher than 600 and $200 \mu \mathrm{g} / \mathrm{L}$ respectively bringing to the reservoir charges of $45 \mathrm{~kg} /$ day (dry season) and $44 \mathrm{~kg} / \mathrm{day}$ (raining season) of total phosphorus. Of these total inputs, $c$. 66-69\% of nitrogen and c. 94.7-99.8\% of total phosphorus are retained in the reservoir, mostly in organic forms (Barbosa et al., 1998).

Several episodes of macrophyte's proliferation and some fish killings had been reported, as well as algae blooms, particularly of Microcystis aeruginosa, M. flos-aquae, M. viridis and Woronochinia naegeliana (Goodwin, 1997).

\section{MATERIALS AND METHODS}

Samples for phytoplankton quantitative analysis were collected bi-weekly from JulyDecember 1996 and January-March 1997 at a fixed sampling station in the reservoir (Fig. 1), using a Van Dorn bottle. Sub-samples were preserved with lugol solution. Qualitative samples were obtained through horizontal throls with a $20 \mu \mathrm{m}$ net and subsamples preserved with neutralized formoldehide solution (4\%). Quantitative analyses were performed under an inverted microscope as described in Sournia (1984) and density expressed according to Villafañe \& Reid (1995). Biovolume of cells and colonies were obtained through the use of a micrometer eye-piece and the formulae described by Edler (1979) and Wetzel \& Likens (1991).

Zooplankton samples were taken with a 68 $\mu \mathrm{m}$ plankton net and short horizontal throls (c. 1 minute each), and the organisms were immobilized by addition of carbonated water and then preserved with $4 \%$ neutralized formoldehyde solution. 


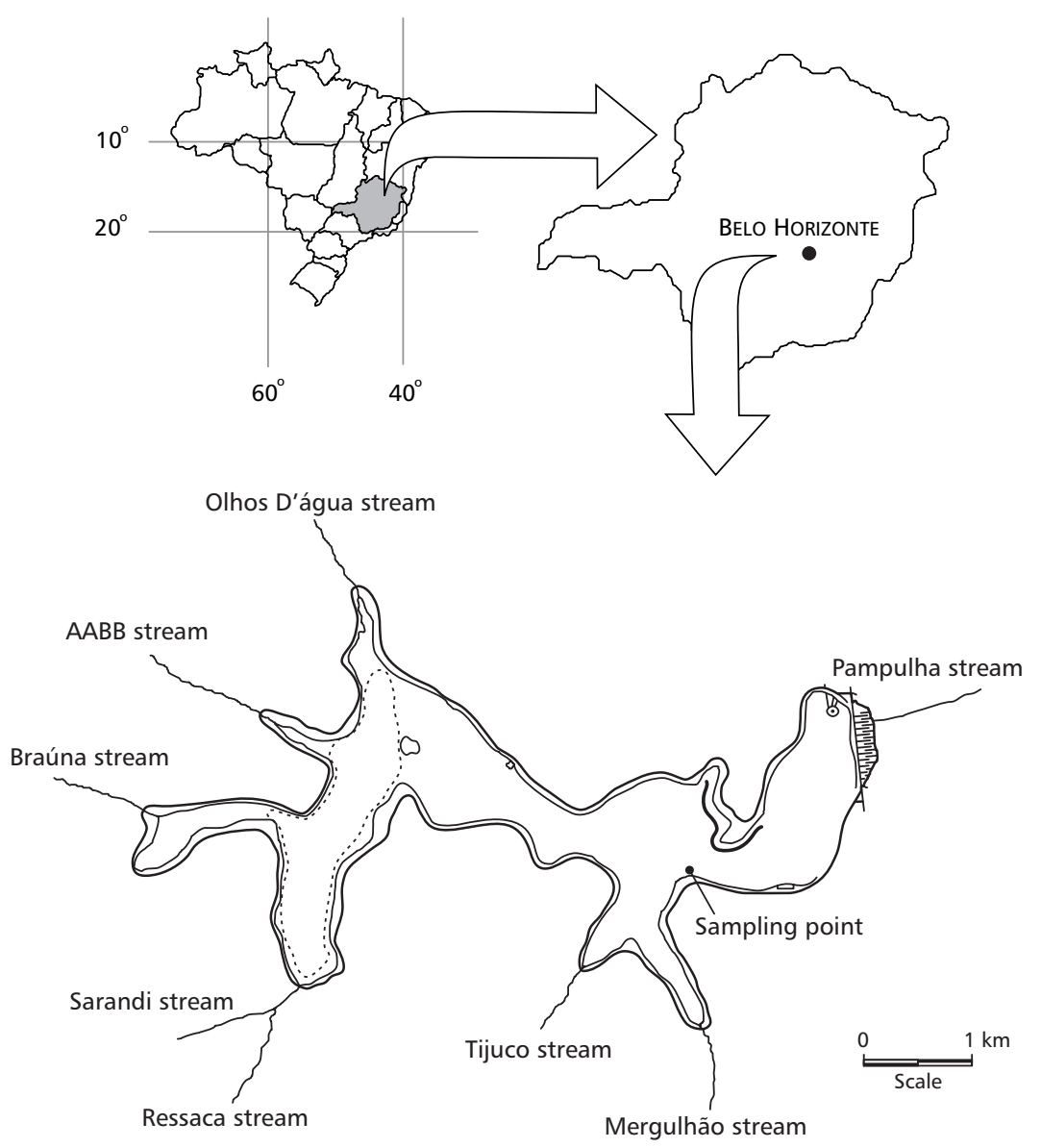

Fig. 1 - Map of Pampulha reservoir showing location of the sampling station.

Adult specimens of D. laevis (> $1.8 \mathrm{~mm}$ ) were isolated in Petri dishes, rinsed with distilled water, and mounted in glass slides. The analysis of the gut content was performed after clarification with sodium hypochlorite according to Infante (1978). The identification and counting of food items were performed using an inverted microscope. The gut content was determined through the counting of the present algae species and the proportion of the digested material. For the scanning microscopy analysis, 30 specimens of $D$. laevis were rinsed with distilled water, fixed with $1 \%$ osmium tetroxide for 2 hours. After dehydration, the digestive tracts were dissected and mounted in glass slides with PolyL-Lisine. The gut content was air dried for 24 hours, metalized with gold and examined under a ZEISS DSM 950 microscope.

\section{RESULTS}

From the 22 microalgae species recorded in the reservoir, 12 were found within the gut content of Daphnia laevis. Chlorophyceae species represented the major food item ingested, from which Eutetramorus fottii, Coelastrum pseudomicroporum, Oocystis lacustris, Chlorella vulgaris, and Chlorococcum sp., were recorded in $90 \%$ of the examined tracts. Furthermore these species were the most abundant within the reservoir (Fig. 2). 


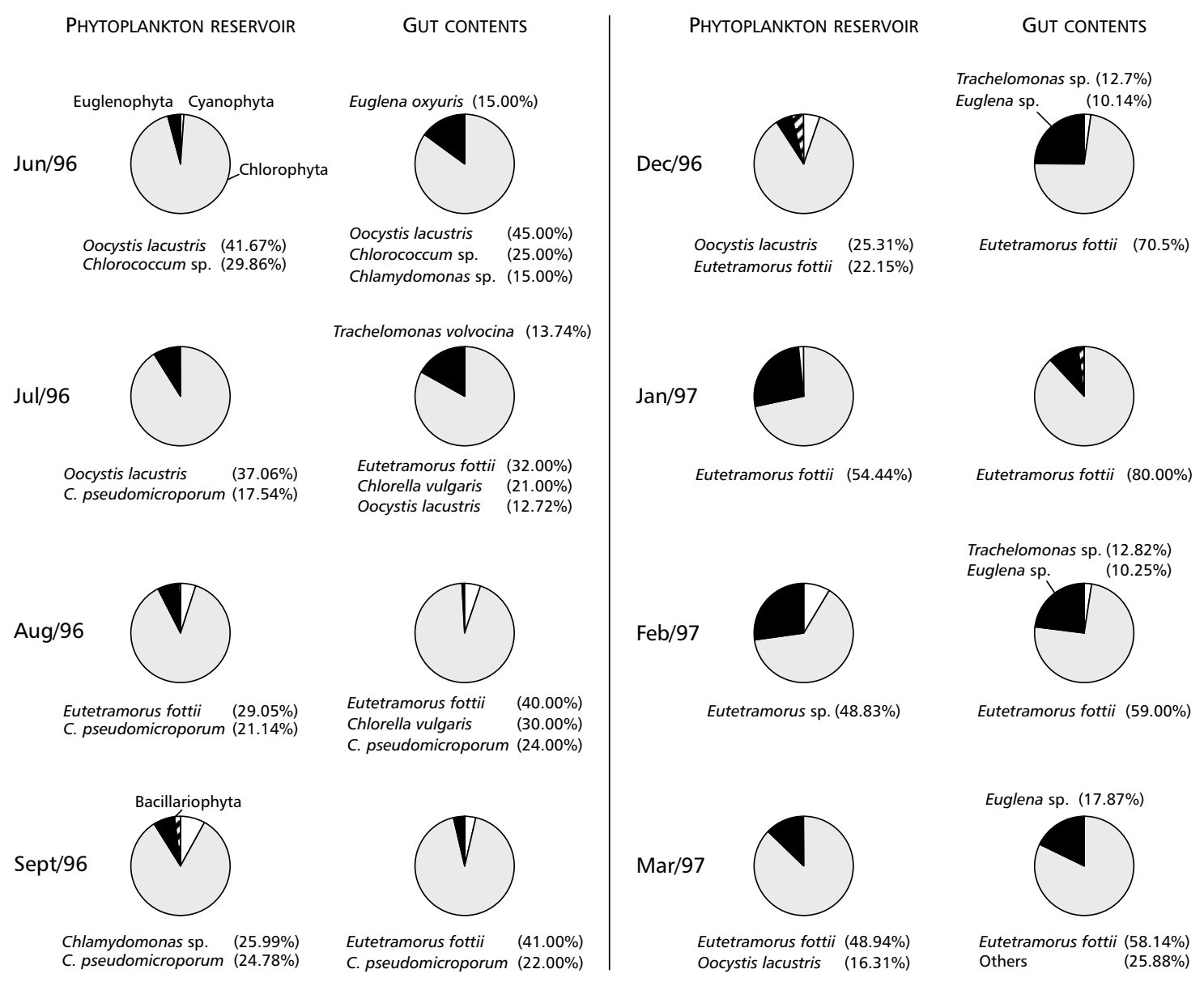

Fig. 2 - Distribution (\%) of total phytoplankton in the reservoir and in the gut content of Daphnia laevis, during the study period.

Besides Chlorophyceae, Euglenophyceae also constitute an important food source, including Euglena oxyuris and Trachelomonas volvocina as major species. Cyanobacteria mainly represented by Microcystis aeruginosa and Anabaena sp. appeared in low abundances within the reservoir, representing less than $15 \%$ of total phytoplankton as well as within the digestive tract of $D$. laevis $(<10 \%$ of ingested food items). Furthermore, non-digested colonies of M. aeruginosa were also found among the gut content.

Microcystis aeruginosa was recorded within the digestive tract just following an observed peak of D. laevis in the reservoir (July 1996), when this species accounted for almost $60 \%$ of the total zooplankton (Fig. 3) decreasing markedly in August (< $10 \%$ of the total zooplankton) increasing again from December 1996 until March 1997.
The algae and D. laevis densities within the reservoir showed an inverse proportional pattern, thus an increase in phytoplankton density was recorded in July (the time of D. laevis peak) and September, followed by a decrease of algae species and an increase of D. laevis population (Fig. 6). The total phytoplankton density within the reservoir oscillated between 35,000 and 540,000 cels. $\mathrm{L}^{-1}$.

Scanning microscopy analysis of the digestive content revealed that besides the ingestion of phytoplankton species, D. laevis also ingested abiogenic material, among which algae fragments were recorded (Fig. 4). During the quantitative peak of D. laevis, the proportion of amorphous material increased considerably, reaching $75 \%$ of the total gut content, while during other periods, this material accounted for less than $15 \%$ of the total gut content. 


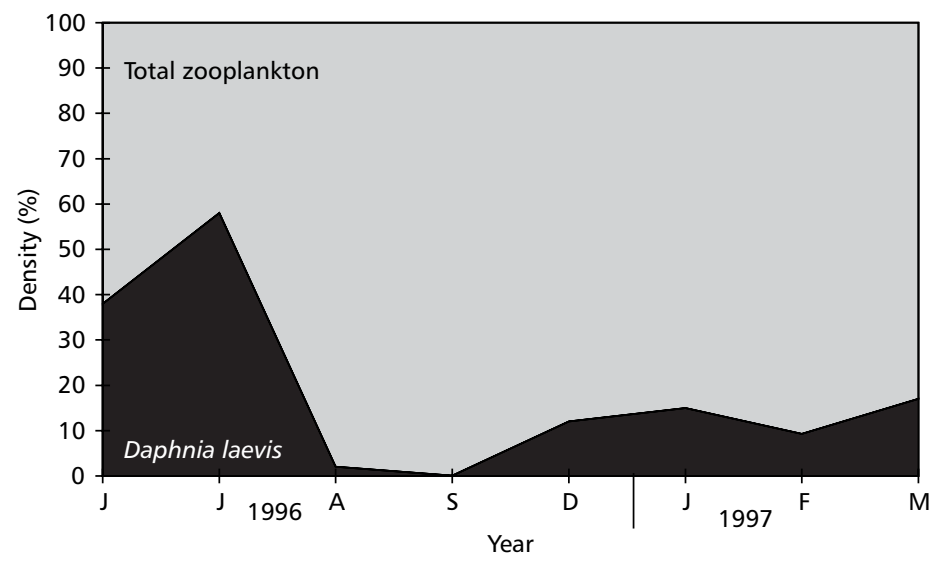

Fig. 3 - Density (\%) of total zooplankton and D. laevis.

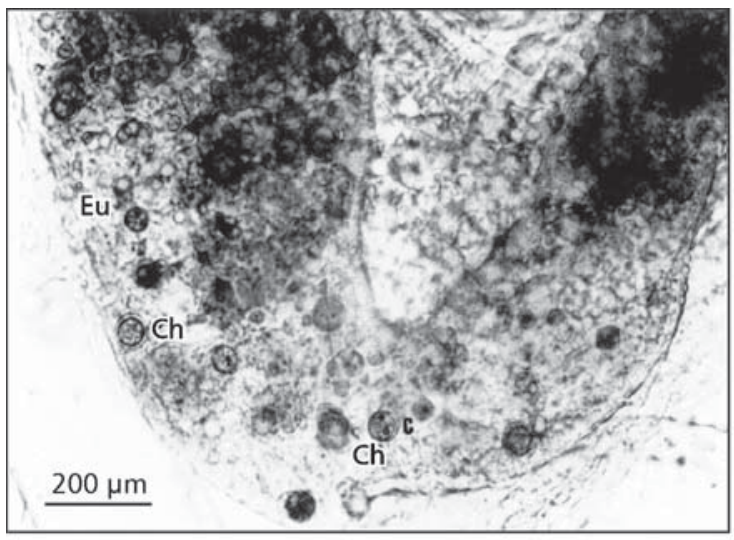

(a) $65 x$

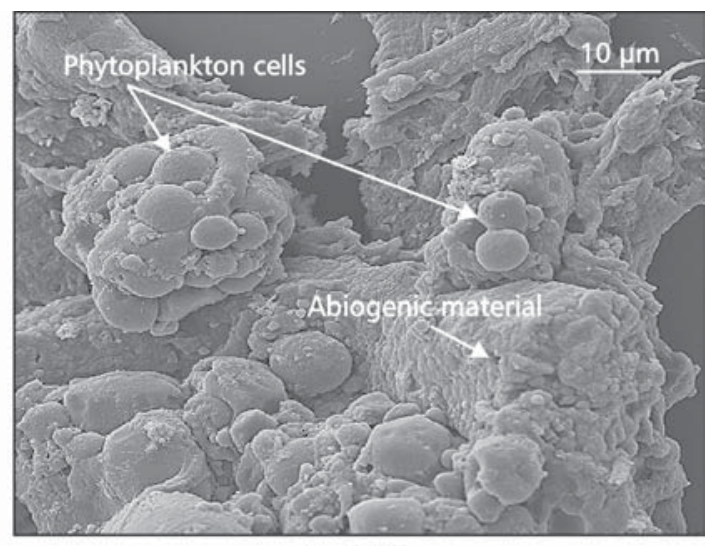

(b) $1000 x$

Fig. 4 - Optical and scanning electron microscopy of the gut content of D. laevis: $(\mathrm{a}):$ Ch = Chlamydomonas sp.; Eu = Eutetramorus fottii. (b): abiogenic material and colonies of undentified phytoplankton cells.

The distribution of algal biomass within the digestive tract of D. laevis was the following: $45 \%$ of the ingested phytoplankton was represented by algae in between 10 and $10 \mu \mathrm{m}^{3}, c .25 \%$ of species of up to $10 \mu \mathrm{m}^{3}$ and $22 \%$ of algae with $1,000 \mu \mathrm{m}^{3}$ (Fig. 5). The phytoplankton cells possessing biomass higher than $10,000 \mu^{3}$ accounted for less than $15 \%$ of the ingested material. Within the reservoir, the most abundant biomass fraction was similar to the one formed by algae in between 10 and $1,000 \mu \mathrm{m}^{3}$, a pattern that changed in August and September when cells with biomass higher than $1,000 \mu \mathrm{m}^{3}$ were dominant, mainly represented by colonies of Eutetramorus fottii, Coelastrum pseudomicroporum, and Microcystis aeruginosa as well as Euglena oxyuris and Phacus sp.

\section{DISCUSSION}

The most abundant phytoplankton species within the reservoir were the predominant ones found in the gut content of D. laevis (Eutetramorus fottii, Coelastrum pseudomicroporum and Oocystis lacustris) thus suggesting no food selection pattern, as similarly recorded by Tóth et al. (1987) for Daphnia galeata. Furthermore, several nondigested cells of Euglena sp. were observed within the digestive tract. 


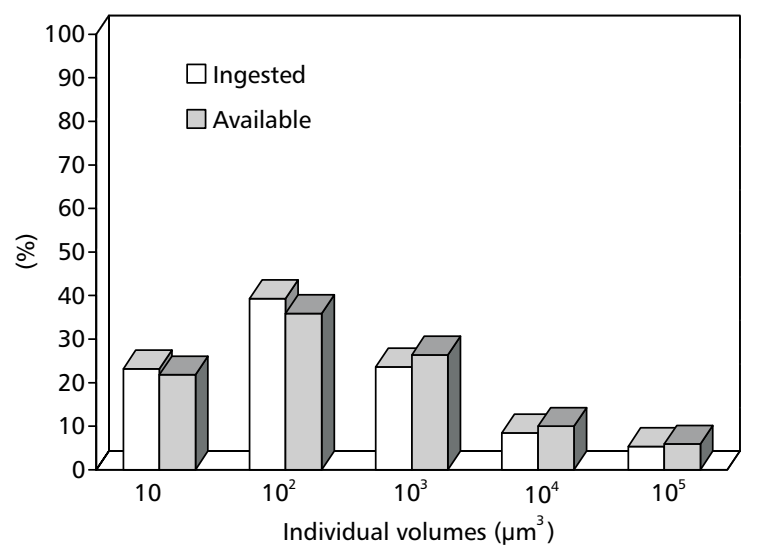

Fig. 5 - Algal biomass distribution in the digestive tract of D. laevis and in Pampulha reservoir, according to cell biovolumes $\left(\mu \mathrm{m}^{3}\right)$.

Similarly the presence of non digested colonies of Microcystis aeruginosa was observed, which according to Gliwicz \& Siedlar (1980), can pass through the digestive tract without being digested due to their mucilage which provide protection against digestive enzymes. Furthermore, the ingestion of $M$. aeruginosa was restricted to the peak period of D. laevis, which seems to be associated with the food availability since both density and species composition of the algae changed during this period.

The viability of cyanobacteria as a food source for the herbivore zooplankton still remains controversial. Some authours suggest that growth and development of planktonic crustaceans can be strongly affected by the ingestion of small bluegreen algae (Alcaraz et al., 1980; Price et al., 1983; Repka, 1998) despite the fact that they have been considered a food source of low nutritional quality (Ahlgren et al., 1990). However, De Bernardi et al. (1981), Holm et al. (1983) and Rietzler \& Espíndola (1998), suggest that the ingestion of blue-green algae can be a strategy to arrest additional food sources without affecting their intrinsic population rates. Furthermore, the possibility of an indirect ingestion of small bluegreens has been discussed, since their mucilage can also contain adehered detritus, bacteria, and protozoa (Amemiya, 1988).

Phytoflagellates were not recorded within the gut content of Daphnia laevis, in spite of the fact that these organisms can represent a reasonable food source considering their small size and quick digestion due to the lack of shell or rigid cell walls (Giani, 1991). The rapid processing of these organisms within the digestive tract probably can explain the difficulty of identifying its fragments in the gut contents, even through the utilization of scanning electron microscopy.

The abiogenic material recorded within the gut content of $D$. laevis showed a considerable variation, coinciding with the quantitative fluctuation of this species in the reservoir. According to Infante \& Edmondson (1985), food resources can interfere with the population dynamics of herbivous zooplankton. Populations of Daphnia can double their densities in the presence of certain type of food resource. On the other hand, under food limitation the population may decline, thus suggesting some restriction in the nutritional quality of the available food source.

The zooplankton utilization of detritus has been described by several authors as a strategy in arresting additional food supplies. The presence of attached bacteria, organic compounds, mainly proteins and carbohydrates, and live phytoplankton cells turn these particles into a rich and diverse food source (Pechen-Finenko, 1987; Navarro et al., 1993; Steinberg, 1995). Furthermore, other factors associated with the occurrence of seasonal patterns of zooplankton distribution, such as predation and changes of physical and chemical parameters of the water also can effectively influence population dynamics. Pinto-Coelho 
(1998) recorded a marked seasonal variation of Daphnia sp. populations in Pampulha reservoir and pointed to the quality of available food source as the key factor in regulating their temporal variations.

The amount of detrital material ingested by D. laevis showed a temporal variation, representing the major food item inside the gut content during the time of the peak of this species. This variation in the predominantly ingested material seemed to have influenced the population dynamics of $D$. laevis, since its densities showed a reduction of $c$. $60 \%$ when the ingestion of detritus was enhanced.

The ingestion of this material seems to be correlated with the type of available food (size and nutritional quality) and also with intra-specific competition for food resources. During the peak of $D$. laevis, the chlorophytes Eutetramorus fottii and Coelastrum pseudomicroporum, represented the major available food item within the reservoir that was ingested by D. laevis. However, just after the boom of $D$. laevis, the biomasses of the phytoplankton species increased considerably from 100 to $10,000 \mu^{3}$. Other micro-algae such as the euglenophytes Euglena oxyuris and Phacus sp., and colonies of Microcystis aeruginosa, also increased both percentages and biomasses.

An analysis of algae biovolumes ingested by D. laevis showed that $45 \%$ of the ingested phytoplankton was formed by cells in between 10 and $100 \mu^{3}$. The change in the availability of cells with this volume range could be constraining the potentially assimilated algae by $D$. laevis, which could be found in the suspended material and additional food source.

The present results suggest that the population dynamics of $D$. laevis can be strongly affected by the type of available food resource that comprises the composition and size of the dominant phytoplankton. In this way, changes in the structure of phytoplankton community induced by processes such as eutrophication can exert a considerable influence on the temporal dynamics of $D$. laevis in Pampulha reservoir.

Acknowledgments - We are grateful to CNPq for the financial support. We also thank Rosa Maria Menendez for phytoplankton identification, and to the Center of Electron Microscopy (CEMEL) of the Federal University of Minas Gerais for using their facilities.

\section{REFERENCES}

AHLGREN, G., LUNDSTEDT, L., BRETT, M. \& FORSBERG, C., 1990, Lipid composition and food quality of some freshwater phytoplankton for cladoceran zooplankters. J. Plankton Res., 12: 809-818.

ALCARAZ, M., PAFFENHÖFER, G. A. \& STRICKLER, J. R., 1980, Catching the algae: a first account of visual observations on filter-feeding calanoids. In: W. C. Kerfoot (ed.), Evolution and ecology of zooplankton communities. The University Press, pp. 241-248.

AMEMIYA, Y., KATO, K. \& NAKAYAMA, O., 1988, Extracellular products of Microcystis species: formation of slime layer and DOC pool in surrounding waters. Verh. Int. Ver. Limnol., 23: 1886-1892.

BARbosA, F. A. R., GARCIA, F. C., MARQUES, M. M. G. S. \& NASCIMENTO, F. A., 1998, Nitrogen and phosphorus balance in a eutrophic reservoir in Minas Gerais: a first approach. Rev. Brasil. Biol., 58: 233-239.

BAYS, J. S. \& CRISMAN, T. L., 1983, Zooplankton and trophic state relationships in Florida lakes. Can. J. Fish. Aquat. Sci., 40: 1813-1819.

DE BERNARDI, R., GIUSSANI, G. \& PEDRETTI, E. L., 1981, The significance of blue-green algae as food for filter-feeding zooplankton: experimental studies on Daphnia spp. fed by Microcystis aeruginosa. Verh. Int. Ver. Limnol., 21: 477-483.

DEMOTT, W. R., 1988, Discrimination between algae and detritus by freshwater and marine zooplankton. Bull. Mar. Sci., 43: 486-499.

EDLER, L., 1979, Recommendations for marine biological studies in the baltic sea. Phytoplankton and Chlorophyll. BMB Publications, n. 5, 38p.

GIANI, A., 1991, Implications of phytoplankton chemical composition for zooplankton production: experimental evidence. Oecologia, 87: 409-416.

GLIWICZ, Z. M. \& SIEDLAR, E., 1980, Food size limitation and algae interfering with food collection in Daphnia. Arch Hydrobiol, 88: 155-177.

GOODWIN, K. L., 1997, Dinâmica das populações de cyanobacteria no reservatório da Pampulha $(M G) \mathrm{em}$ duas escalas temporais (sazonal e diurna). Tese de Doutorado, Universidade Federal de Minas Gerais, 110p.

HANAZATO, T. \& YASUNO, M., 1987, Evaluation of Microcystis as food for zooplankton in a eutrophic lake. Hydrobiologia, 144: 251-259.

HARTMANN, H. J. \& KUNKEL, D. D., 1991, Mechanisms of food selection in Daphnia. Hydrobiologia, 225: 129154.

HOLM, N. P., GANF, G. G. \& SHAPIRO, J., 1983, Feeding and assimilation rates of Daphnia pulex fed Aphanizomenon flos-aquae. Limnol. Oceanogr., 28: 677-687.

INFANTE, A., 1978, A method for the study of foods of herbivorous zooplankton. Trans. Am. Micros. Soc., 97: 256-258. 
INFANTE, A. \& EDMONDSON, W. T., 1985, Edible phytoplankton and herbivorous zooplankton in Lake Washington. Arch. Hydrobiol., 21: 161-171.

INFANTE, A. \& RIEHL, W., 1984, The effect of cyanophyta upon zooplankton in a eutrophic tropical lake (Lake Valencia, Venezuela). Hydrobiologia, 113: 293-298.

MAYER, J., DOKULLI, M. T., SALBRECHTER, M., BERGER, M., POSCH, T., PFISTER, G., KIRSCHNER, A. K. T., VELIMIROV, B., STEITZ, A. \& ULBRICHT, T., 1997, Seasonal successions and trophic relations between phytoplankton, zooplankton, ciliate and bacteria in a hypertrophic shallow lake in Viena, Austria. Hydrobiologia, 342/343: 165-174.

NAVARRO, J. M., CLASING, E., URRUTIA, G., ASENCIO, G., STEAD, R. \& HERRERA, C., 1993, Biochemical composition and nutritive value of suspended particulate matter over a tidal flat of southern Chile. Estuar. Coast. Shelf Sci., 37: 59-73.

NÕGES, T., 1997, Zooplankton-phytoplankton interactions in lakes Võrtsjärv, Peipsi (Estonia) and Yaskhan (Turkmenia). Hydrobiologia, 342/343: 175-183.

PECHEN-FINENKO, G. A., 1987, The nutritive value of the detritus for the marine plankton animals. IFREMER Act. Coll., 5: 171-180.

PINTO-COELHO, R. M., 1998, Effects of eutrophication on seasonal patterns of mesozooplankton in a tropical reservoir: a 4-year study in Pampulha Lake, Brazil. Freshwat. Biol., 40: 159-173.

PRICE, H. J., PAFFENHÖFER, G. A. \& STRICKLER, J. K., 1983, Models of cell capture in calanoid copepods. Limnol. Oceanogr., 28: 116-123.
REPKA, S., 1997, Effects of food type on the life hystory of Daphnia clones from lakes differing in trophic state. I. Daphnia galeata feeding on Scenedesmus and Oscillatoria. Freshwat. Biol., 37: 675-683.

REPKA, S., 1998, Effects of food type on the life history of Daphnia clones from lakes differing in trophic state. II. Daphnia cucullata feeding on mixed diets. Freshwat. Biol., 38: 685-692.

RIETZLER, A. C. \& ESPÍNDOLA, E. L. G., 1998, Microcystis as food source for copepods in a subtropical eutrophic reservoir. Verh. Int. Ver. Limnol., 26: 20012005.

SOURNIA, A., 1984, Phytoplankton manual. Unesco, 337p.

STEINBERG, D. K., 1995, Diet of copepods (Scopalatum vorax) associated with mesopelagic detritus (guant larvacean houses) in Monterey Bay, California. Mar. Biol., 122: 571-584.

TÓTH, L. G., ZÁNKAI, N. P. \& MESSNER, O. M., 1987, Algal comsuption of four dominant planktonic crustaceans in Lake Balaton (Hungary). Hydrobiologia, 145: 323-332.

VILLAFAÑE, V. E. \& REID, F. M. H., 1995, Métodos de microscopía para la quantificación del fitoplancton. In: K. Alveal, M. E. Ferrario, E. C. Oliveira \& E. Sar (eds.), Manual de métodos ficológicos. Universidad de Concepción, Chile, pp. 169-185.

WETZEL, R. \& LIKENS, G. E., 1991, Limnological analyses. Springer Verlag, 391p. 